\title{
Environmental diagnosis of hazardous household wastes and the family health strategy as liaison for implementation of a management program in the South of Brazil
}

\author{
Diagnóstico ambiental de resíduos domésticos perigosos \\ e a estratégia de saúde da família como elo para implementação de \\ um programa de gestão no Sul do Brasil
}

\author{
André Preissler Loureiro Chaves ${ }^{1}$, Roni Bitencourt da Silva ${ }^{2}$
}

\begin{abstract}
Despite the serious threat to public health that it represents, hazardous household waste $(\mathrm{HHW})$ is not perceived as dangerous by a majority of the population. Existing waste management systems contribute to this misperception, by underestimating the importance of these residues. This, in practice, reflects the lack of knowledge of citizens about the risks and about their responsibility. This study aimed to identify the major HHW generated and disposal practices of the population of São Luís District and know the HHW management situation of the municipality of Canoas, Brazil. We conducted a neighborhood survey, identifying the generation and destination of 15 types of HHW. The situation of the management of this waste was obtained through consultations with the City of Canoas, where we observed little effective action to correct mismanagement. With the aim of improving the current administration, this paper proposes the use of the Family Health Strategy as a liaison for implementation of an appropriate hazardous household waste management program. The role of Community Health Workers restates the important potential for the integration of environmental education and preventive action.
\end{abstract}

Keywords: hazardous household waste; family health strategy; environmental health; reverse logistics; primary health care

Resumo

Apesar da grave ameaça para a Saúde Pública que representa, os resíduos domésticos perigosos (RDP) não são percebidos como danosos pela maioria da população. Sistemas de gestão de resíduos existentes contribuem para essa percepção, por subestimar a importância desses resíduos. Isso, na prática, reflete a falta de conhecimento dos cidadãos sobre os riscos e sobre a sua responsabilidade. Este estudo teve como objetivo identificar os principais RDP gerados e as práticas de eliminação por parte da população do Bairro São Luís, em Canoas, no Rio Grande do Sul, e conhecer a situação da gestão dos RDP pela Prefeitura de Canoas. Foi realizado um levantamento no bairro, identificando a geração e o destino de 15 tipos de RDP. A situação da gestão desses resíduos foi obtida por meio de consultas na Administração Municipal, na qual foram observadas poucas medidas eficazes para corrigir a má gestão. Com o objetivo de melhorar a gestão atual, o presente trabalho propõe o uso da Estratégia Saúde da Família como uma ligação para a implementação de um programa de gestão de RDP apropriado. O papel dos Agentes Comunitários de Saúde reafirma seu importante potencial para a integração da educação ambiental e da ação preventiva.

Palavras-chave: resíduos domésticos perigosos; estratégia saúde da família; saúde ambiental; logística reversa; atenção primária.

${ }_{1}^{1} \mathrm{PhD}$ in Public Health, Universidade de São Paulo (USP), visiting Researcher at Centre for Environmental Strategy (CES), University of Surrey, Guildford/UK. Programa de Pós-graduação em Saúde Coletiva of Universidade Luterana do Brasil (ULBRA) - Canoas (RS), Brazil.

${ }^{2}$ Specialization in Engineering work safety. Works at Hospital Moinhos de Vento, Porto Alegre (RS), Brazil.

Study carried out at Post Graduate Program in Public Health (PPGSC), Universidade Luterana do Brasil (ULBRA) - Canoas, RS, Brasil

Correspondence: André Preissler Loureiro Chaves - Rua Conde de Porto Alegre, 550, apto.1801 - CEP: 90220-210 - Porto Alegre (RS), Brasil -

Email: andreplc@terra.com.br

Financial support: none.

Conflicts of interests: nothing to declare. 


\section{INTRODUCTION}

Until recently, solid waste was considered as low risk to the environment. However, whether due to the introduction of new products, or the increased knowledge of the impacts of certain materials in the environment, or by increasing the amount thereof, these materials began to pose a threat to the integrity of the environment by containing items which may be classified as hazardous ${ }^{1}$. While hazardous household waste (HHW) represents a relatively small proportion of current urban solid residues, it is the most toxic part of the waste stream ${ }^{2,3}$.

In the USA, for the Environmental Protection Agency (USEPA), leftover household products that contain corrosive, toxic, ignitable, or reactive ingredients are considered to be $\mathrm{HHW}^{4}$. No legal requirement exists in the UK for householders to separate HHW from general household waste ${ }^{5,6}$. The term used to refer to hazardous waste generated in households at a municipal level is not clearly defined in current European Union (EU) legislation, and there is no specific regulation specifying the appropriate management of such waste ${ }^{6}$.

In Mexico, hazardous waste has been defined as "[...] those wastes in any physical state, that by any characteristic represent a hazard to the ecological or environmental balance [...]" (p. 5) 7, $^{7,}$. In Brazil, to categorize a waste as hazardous, it has to be analyzed according to the standards of the National Solid Waste Policy 9

Within this framework, this study aimed to identify the major HHW generated by the population of São Luís District and their disposal practices and know the situation of the management of HHW by the municipality of Canoas (RS). Finally, it proposes to link the use of community health teams from the Family Health Strategy (FHS) in the Health System to address this problem.

Automotive batteries, automotive oils, batteries, cleaners, cooking oil, cosmetics, fluorescent lamps, inks, insect repellents, pesticides, solvents, thermometers, tires, veterinary products and other automotive products were considered components of HHW covered by the study. These waste classes were defined based on consultation of the literature, considering the most often produced ${ }^{5,10}$. Despite also being considered HHW, unused/expired drugs and electronic waste were not the objects of this work, due to their special characteristics, though they deserve to be targets for other specific studies ${ }^{11,12}$.

\section{Effects of hazardous household waste in the human being}

Chemicals found in household products can enter the body and cause adverse health through ingestion, absorption or inhalation effects. Examples of acute effects of these products include poisoning by a toxic substance such as antifreeze, acid burns from a product like battery acid, or injury by an aerosol can exploding close to a stove. Some products emit toxic gases, which can produce acute reactions such as headaches, fatigue, burning eyes, runny nose, and rashes ${ }^{3}$. Chronic health effects may result from recurrence or long-term exposure to highly toxic products such as automotive products, solvents, oil-based paints, or pesticides ${ }^{13,14}$.

Exposure to pesticides can occur through food, drinking water, indoor and outdoor household and professional use (including structural application and agriculture). Children are exposed to pesticides used on school grounds and parks as well as home backyards. Children are particularly susceptible to the "toxic dust from home." With their rapidly developing bodies, they are more prone to damage as they have a small fraction of the body weight of an adult and can ingest five times more powder-100 mg per day on average ${ }^{15}$. Children may experience neurological effects as well as increased cases of asthma and allergies from exposure to pesticides.

Improper storage of hazardous household products can lead to accidental spills. A spill of hazardous materials during an earthquake, flood, fire or hurricane adds to the dangers of these disasters, increasing the risk of contamination ${ }^{16}$.

Organochlorine insecticide can accumulate along the food chain, positioning itself in the fat of fish, cattle, poultry and other animals, and breast milk, as well as in plants, fruits and water that have been exposed to these substances, creating an ecological and public health problem ${ }^{17}$.

Heavy metals have been extensively studied and their effects on human health regularly reviewed by international bodies such as the World Health Organization ${ }^{18}$. In spite of the fact that health effects of heavy metals have been known for a long time, exposure to heavy metals continues, in particular, in developing countries ${ }^{13,14,19}$.

\section{Family health strategy}

The Unified Health System (SUS) was established in the 1980s, following the demise of the military regime. It is one of the first attempts to make healthcare a social responsibility under the new democratic system ${ }^{20,21}$. SUS is centered on primary health care; it aims to provide universal access to comprehensive health care. Primary Care is key to reducing overall demand in the public health system to more complex levels of care $\mathrm{e}^{22-24}$.

The FHS, given its characteristics, falls outside the usual programs, by characterizing itself as a strategy that enables integration and promotes the organization of activities in a defined territory in order to face and solve the problems identified ${ }^{20,21}$. The FHS is understood as a strategy for reorienting the care model, operationalized through the implementation of multidisciplinary teams in primary healthcare units ${ }^{25}$. 
The work of the Family Health teams is the key to the ongoing search for communication and exchange of experiences and knowledge among team members, and this information is also shared with the Community Health Worker. Teams are made up of, at least, a family doctor, a nurse, a nursing assistant and six community health agents.

Each team is responsible for monitoring a maximum of 4000 inhabitants of a particular area, and these shall have co-responsibility for health care. The teams are engaged primarily in basic health units, homes and the community. They are characterized as an input port within a hierarchical regionalized health system, having defined territory, with a defined population under their responsibility. Also worth considering are the risk factors to which the community is exposed, for which the teams provide integral, permanent and quality care and conduct educational activities and health promotion ${ }^{25}$.

The Family Health teams, working properly, are able to solve $85 \%$ of the health problems in their community, providing quality care, preventing diseases, avoiding unnecessary hospitalizations, and improving the quality of life of the population ${ }^{20}$.

The Program Community Health Workers is considered part of the FHS. The actions of Community Health Workers (CHW) are accompanied and guided by a nurse/supervisor positioned within a basic health unit ${ }^{25}$.

\section{MATERIALS AND METHODOLOGY}

The present paper is an exploratory and descriptive, qualitative research, designed to achieve its goals by conducting a survey and making use of a questionnaire, to create subsidies for the problem presented.

\section{Study area: The Sao Luis District}

The Sao Luis District, located in Canoas, Rio Grande do Sul state, southern Brazil, has a population of 4317 inhabitants, with 1392 permanent private households ${ }^{26}$. Of these, 1356 (97.56\%) are served by waste collection services. However, the amount of solid waste collected per capita, in 2010, reached $0.66 \mathrm{~kg} /$ inhab.day, an amount far below the Brazilian average of $1.1 \mathrm{~kg} /$ inhab.day ${ }^{27}$.

The city of Canoas is located $13.5 \mathrm{~km}$ from Porto Alegre, the state capital. It is the most populous municipality in the metropolitan area, with 329,174 inhabitants, and has the second highest gross domestic product (GDP) of the state. The city occupies an area of $131,097 \mathrm{Km}^{2}$ and is divided into 18 districts $^{26}$. The Sao Luis District was chosen as the study area to be representative of the city's features, and because it is located near the Alberto Pasqualini Refinery (REFAP), the largest refinery in the region, which belongs to the Petrobras Oil Company ${ }^{28}$.

\section{Team family health strategy}

The FHS is present in six neighborhoods in the city of Canoas, and currently has 13 teams spread throughout the municipality. The Sao Luis District team is based in the Health Center located at Rua Teófilo Otoni, No. 268 and serves 1320 families ( $94.8 \%$ of total), reaching 4100 people. The team meets the neighborhood population from 8 am to $5 \mathrm{pm}$, Monday to Friday, and is composed of the following professionals: two physicians, one nurse, two nursing staff, one dentist, one dental assistant, three health workers, one hygienist, and two booth attendant ${ }^{28}$.

\section{Identification of major hazardous household waste generated and disposal by the population}

The identification of major HHW generated by the São Luís neighborhood community, and collation of the information provided by the population, occurred through the administration of a community questionnaire. The questionnaire contained questions about the sociodemographic characteristics of the population, household hazardous waste generated (class and estimated quantity generated), and disposal of the waste by the population (door-to-door collection, tippers and trucks, voluntary delivery points, community dumpsites, streets, gutter or waste burning). Although not exactly a research participant, this work assumes the same characteristics and assumptions, since "participation" takes position in the research process by changing the classic role of "informant", becoming "active subject" both in construction of knowledge and in action ${ }^{29}$.

First, the questionnaire was applied experimentally in the Sao Jose neighborhood, as a way to pre-test the instrument. The Sao Jose District was chosen to have the same characteristics as the target neighborhood. In the Sao Luis District questionnaire we sought to circumscribe the central area of the neighborhood, because it is the area of highest population density. The criterion was to visit homes and interview 10 residents in 10 homes. In case of refusal to participate in research or lack of an occupant at a residence, the previous house was chosen for the sample, and so on. The questionnaire was administered between March and May 2013, in six major streets in the Sao Luis District, as shown in Table 1.

In total, 96 people were interviewed. It should be emphasized that while this is not a statistically significant sample, it is, however, a significant sample from the standpoint of the purposes of the study.

Situation of the management of hazardous domestic waste by the city of Canoas identified in this work

The description of the situation of the management of the HHW identified in this work, in Canoas was performed by consulting the municipal Departments of Environment and 
Health. These consultations are provided through the municipality by means of access to manuals and other educational materials published on the city website, as well as phone calls and interviews for those responsible for waste management with the use of semi-structured questions: How is HHW managed in the City? How often are there collection/sampling campaigns for the waste mentioned above? How many districts are served by the collection of such waste? How is the population informed about the management of such waste? Does the municipality forward waste to any specialized company?

To carry out consultation with the Secretaries, the snowball methodological technique was adopted. This technique is a form of non-probability sampling used in research where the original participants of a new study indicate other participants that, in turn, point to new participants, and so on, until the proposed goal (the "saturation point") is reached ${ }^{30}$.

The information on the management of $\mathrm{HHW}$ identified in this work situation was provided by the Environmental Engineer (Department of Environment), the Director of Selective Collection and Waste Control, and the Civil Engineer responsible for the local landfill. The interviews took place during the months of September 2012 and June 2013. HHW that were the target of this consultation, together with the municipality, were the same wastes covered by the study at the Sao Luis neighborhood community.

This study was approved by the Ethics Committee of the Comun. Evangelical Lutheran São Paulo (CELSP)/Lutheran University of Brazil (ULBRA, Campus Canoas/RS) and the National Research Ethics Commission (CONEP), Brazil, as CAAE 24846413.1.0000.5349.

\section{RESULTS AND DISCUSSION}

\section{Sociodemographic characteristics of the population}

With regard to sociodemographic data, the results obtained in the 96 homes visited are presented ahead. Of the individuals interviewed, 35 (36.5\%) were females and 61 (63.5\%) were males. This difference between the sexes of the respondents can be explained by the type of approach, given the fact that during

Table 1. Number of households visited by street, Sao Luis District - Canoas VISITED STREETS $\mathrm{N}^{\circ}$ OF VISITED RESIDENCES

\begin{tabular}{cc} 
Berto Círio & 12 \\
Teófilo Antoni & 12 \\
Eng ${ }^{\circ}$ Rebouças & 12 \\
Sen. Salgado Filho & 24 \\
Brig. Ivo Borges & 12 \\
Evaristo da Veiga & 24 \\
TOTAL & 96 \\
\hline
\end{tabular}

the application of the research, usually the head of household was responsible for assisting the researcher.

Regarding the level of education of respondents, 45 (47\%) had middle level, 20 (21\%) incomplete primary school, 17 (18\%) elementary school, 13 (13\%) higher education, and one incomplete higher education. Approximately $86 \%$ of the interviewed population is distributed between the elementary and secondary levels. Although not to be treated in itself as a statistically significant sample, this finding should be taken into account in the implementation of future programs of environmental education. As seen in Figure 1, a fact that drew attention was the long residence time of the neighborhood residents in the community.

The population with over 10 years of residence in the district represented $82.3 \%$ of the total. More than $60 \%$ of the people interviewed are residents with more than 20 years living in the neighborhood. This finding is important because it defines a population profile of significant benefit to the application of future management programs. The human geography concept of "sense of place" is consistent with the environmental psychology notion of place attachment. When viewed from the standpoint of this latter discipline, attachment represents an emotional or affective bond between a person and a particular place: a sense of belonging. This conception is very important when planning environmental education projects ${ }^{31,32}$.

\section{Major hazardous household waste generated by the community}

The identification of waste generation showed the behavior described in Table 2. With regard to waste, it can be seen that all items listed in this paper and presented to the population were generated.

In order, batteries, cooking oil, fluorescent lamps, paints, cosmetics/toiletries and solvents were the wastes most accumulated

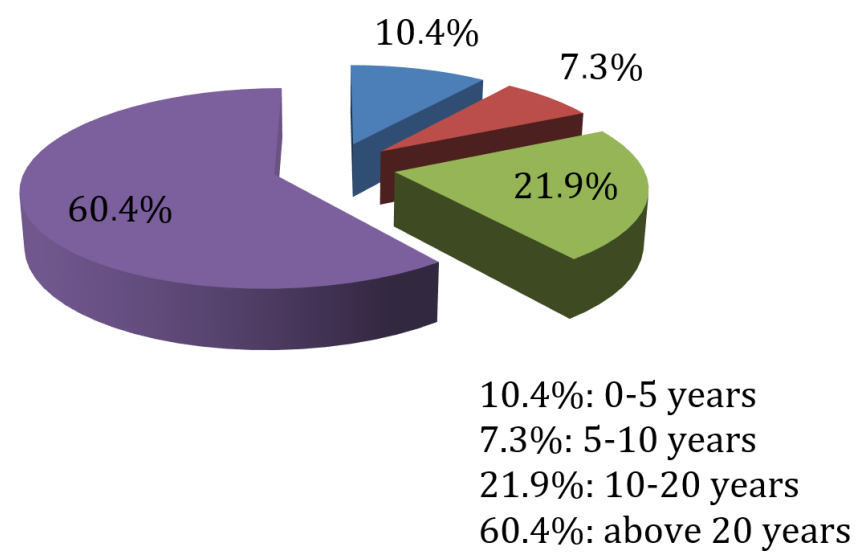

Figure 1. Characterization by length of residence in the district, Sao Luis community 
by locals. These six classes of waste were generated in more than $50 \%$ of homes. Although the amounts of waste generated are important to know the real danger that an incorrect management implies ${ }^{6,19,33}$, the amounts of every waste type generated cannot be indicated due to the data quality, as during the survey, to estimate the quantities generated, the interviewees did not follow standard units of measure, which prevented the data from being added. This methodological aspect should receive attention in any future similar works.

\section{Destination of the waste by the population}

Using the collected data, a comparison chart was drawn between the two forms of allocation considered by the study (adequate or inadequate) for the 15 covered HHW items. The results are shown in Figure 2. The study considered door-to-door collection, tippers and trucks, or voluntary delivery points as

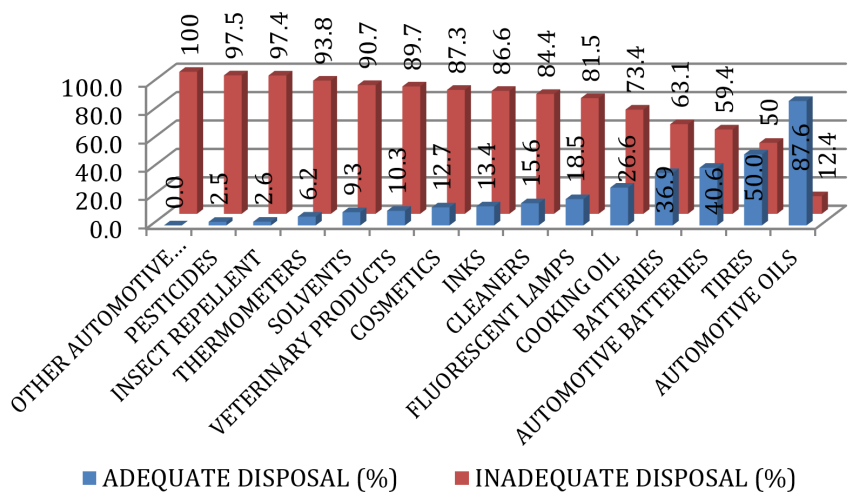

Figure 2. Comparison between adequate and inadequate disposal of Household Hazardous Waste, Sao Luis District adequate disposal and community dumpsites, streets, gutters, or waste burning as inadequate disposal ${ }^{34}$.

In the data analysis, it was found that automotive oils and tires with $87.6 \%$ and $50 \%$, respectively, were the only wastes which reached at least $50 \%$ of suitable targets. It is important to notice, however, that these two classes of waste were generated in less than $19 \%$ of the homes. Of the remaining 13 residues, all exceeded 50\% of unsuitable destinations, which clearly demonstrates that, in general, the population is disposing of HHW inappropriately, either through ignorance of the risks, or for lack of convenient logistic conditions.

Like in a study developed in Nigeria ${ }^{34}$, many of the households throw away their waste at communal dumpsites, on the streets and waterways and drains. This is worrying as communal dumpsites encourage proliferation of mechanical and biological vectors and aid in the spread of infectious diseases with a serious public health issue.

Two automotive products: "automotive oils" with the highest percentage of appropriate target, and "other automotive products" with the highest percentage of inappropriate target occupy the two extremes of Figure 2. This shows that the risk perception of the population is not adequate, because it is the waste of an item from the same product group.

Mass environmental education campaigns on the harmful effects of indiscriminate disposal of waste and the provision of adequate home collection services should be implemented.

\section{Education level vs. disposal of major waste generated}

From the amounts of six major HHW products generated in São Luís District (Table 2) a comparative destination of these

Table 2. Identification of the waste generated by the Sao Luis community

\begin{tabular}{|c|c|c|}
\hline WASTES & $\begin{array}{c}\text { GENERATION OF WASTE } \\
\text { NUMBER OF HOMES THAT GENERATE } \\
\text { THIS WASTE }\end{array}$ & $\begin{array}{c}\text { \% RESIDENCES THAT GENERATED } \\
\text { THIS WASTE }\end{array}$ \\
\hline Batteries & 84 & 87.5 \\
\hline Cooking oil & 83 & 86.5 \\
\hline Fluorescent lamps & 81 & 84.4 \\
\hline Paints & 67 & 69.8 \\
\hline Cosmetics & 55 & 57.3 \\
\hline Solvents & 54 & 56.3 \\
\hline Pesticides & 40 & 41.7 \\
\hline Insect repellent & 38 & 39.6 \\
\hline Automotive batteries & 37 & 38.5 \\
\hline Cleaners & 32 & 33.3 \\
\hline Veterinary products & 29 & 30.2 \\
\hline Tires & 18 & 18.8 \\
\hline Automotive oils & 16 & 10.7 \\
\hline Thermometers & 16 & 16.7 \\
\hline Other automotive products & 4 & 4.2 \\
\hline
\end{tabular}


residues was drawn with the education level of respondents. The results found are shown ahead (Figure 3).

As it can be seen in Figure 3, the overall analysis of six waste products generated by most of the Sao Luis neighborhood community relating to the level of education revealed that for batteries, cooking oil and fluorescent lamps, the level of education had a positive influence on proper disposal. For paints, cosmetics/toiletries and solvent residues, this trend was not confirmed.

It is noteworthy that, regardless of level of education, in general, the percentage of inappropriate discharges remains high, which proves the absence of an effective management program for these residues. This can denote that the level of knowledge would not be enough for someone to behave responsibly towards the environment. As studies show ${ }^{35}$, recycling is a reflection of balanced self-interest: an integrated balance in self (egoism) and other (altruism) interests-the interest of society as a whole.

\section{Management of hazardous household waste by the municipality of Canoas}

The data obtained in the Municipality of Canoas are as follows:

- Management of the HHW in the city of Canoas: there are effective measures for waste management only for paints and solvents (voluntary delivery points) and waste tires. For other wastes, there is no management.

- Collection/sampling campaigns for waste mentioned waste tires: according to the demand through phone calls informing of the improper disposal and collection requests. Paints and solvents: no frequency was defined. Other wastes: no collection.

- Information about the management of HHW: the population is informed when they call or come in contact with the city government, through the Environmental Secretary.

Only for tires, paints and solvent residues were effective actions for Waste Management observed, highlighting the partnership with the city government for private gathering by tire companies. However, paints and solvents are just stored in building belonging to the Environmental Secretary. Analyzing this data, and comparing the results, it is evident that government action positively influences the appropriate management of HHW, noting that the waste tire got the 2 nd best result with respect to appropriate discharges.

Following this line of analysis, the lack of a program for the effective management of HHW negatively influences the results related to proper disposal. This relationship can be seen clearly in Figure 3, which shows high rates of improper disposal for virtually all waste types. The lack of information about collection

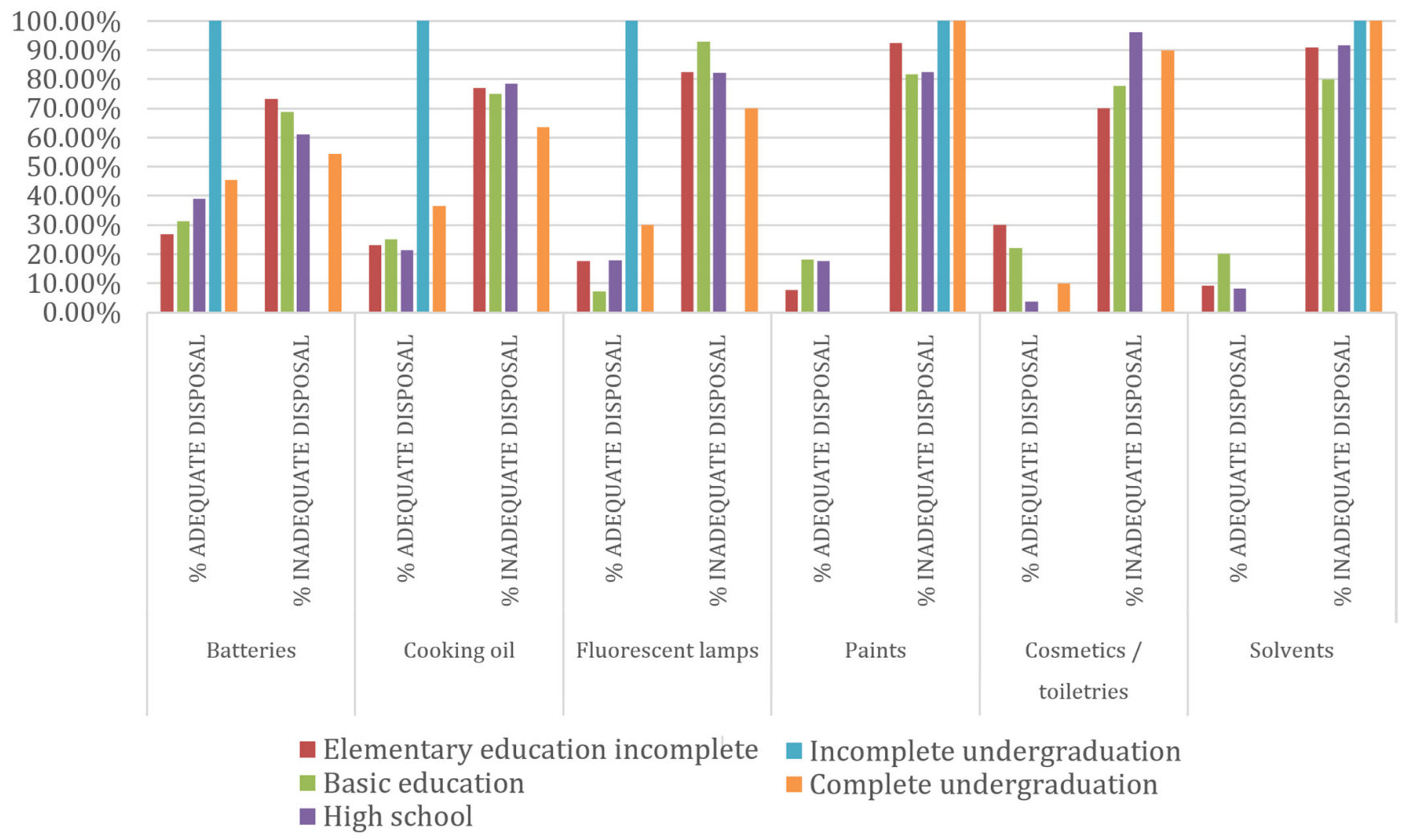

Figure 3. Education level vs. disposal of major waste generated, Sao Luis District 
points and other actions to raise awareness of the population is another aspect identified and directly influences the results obtained in this work. It was found that the collection points (voluntary delivery points), almost entirely, were deprived points.

Public perceptions of the relative health risks from hazardous waste reflect not only differences in understanding but also underlying social values ${ }^{36}$. In the twenty-first century, often, who decides what would be a risk in a territory usually does not belong to it. The development of risk assessment participatory programs is essential to ensure the public right and responsibility to be involved in the management of hazards in their communities.

The CHW is the link between the residents and the FHS. Of necessity residing in the locality of action, they know the problems faced by the community, and the demands and needs peculiar to each user. Access to the residences of the same users is easier because of this proximity, allowing all of them to know the problems faced by families ${ }^{37}$.

\section{Proposed Waste Management Facility: The Family Health Strategy}

One of the proposed mechanisms is the use of $\mathrm{CHW}$ as disseminators of information and official materials from City Hall about HHW. Another possible duty of CHW would be to inform the local population about how the city is managing the HHW collection points as well as about possible risks involving the improper handling and disposal of such waste for public health and the environment. Cities are complex systems, so urban health outcomes are dependent on many interactions. Urban planning for health needs should focus on experimentation through projects ${ }^{38}$.

This integration between $\mathrm{CHW}$, the community, and institutions of Public Power can positively influence the population, because the CHW act directly with the homes in a community ${ }^{22,23,28}$. However, this coordinated action implies the proper training of CHW. Some of the topics that can be addressed are listed ahead:

- HHW risks involved: environmental considerations and public health;

- Risk of accidents in the home;

- Safety aspects in the handling of waste;

- Collection points available in the city (public and private);

- National Policy on Solid Waste;

- Responsibilities for disposal of solid waste.

Depending on the level of education required when selecting and hiring $\mathrm{CHW}$, it is suggested that accessible language and use of videos be employed, with the aim of facilitating the understanding of everyone involved. It is considered that the appropriate use of lightweight social technologies by the public power may result in a change of scenery ${ }^{39}$.

\section{CONCLUSIONS}

This study identified the major hazardous household wastes generated by the population of the São Luis District in the municipality of Canoas, Rio Grande do Sul state, Brazil. In order, batteries, cooking oil, fluorescent lamps, paints, cosmetics/toiletries and solvents were the wastes most accumulated by locals. These six classes of waste were generated in more than $50 \%$ of homes. The vast majority of $\mathrm{HHW}$ is being disposed of improperly: community dumpsites, streets, gutter, or waste burning. In the data analysis, it was found that automotive oils and tires, with $87.6 \%$ and $50 \%$, respectively, were the only wastes which reached at least $50 \%$ of suitable targets.

There are effective measures for HHW management by the Municipality of Canoas only for paints and solvents (voluntary delivery points) and waste tires. It is noteworthy that, regardless of the level of education, in general, the percentage of inappropriate discharges remains high, which proves the absence of an effective management program for these residues.

An integrated strategy between government, community, and the private sector is needed. The use of the FHS as a link to the implementation of a program of HHW management is an alternative to the effective enforcement of the National Solid Waste Policy, which states that consumers should return some HHW to traders or distributors after use.

The pyramid base of the SUS, in Brazil, is the primary care, compounded of community health centres. Provisions established by the primary care represent a strategy to contribute to addressing the problems of environmental health. The territory covered by the FHS and its intersectoral operations must be known to identify risk situations from the perspective of primary environmental care.

The role of CHW, in this sense, through home visits, has significant potential in preventing improper disposal of these wastes. Adequate training and the use of these health sector workers, as a link in the dissemination of information on collection sites (public or private) as well as risks to public health and the environment, may contribute to the improvement in the disposal of such waste, not only in São Luís District, but also in other contexts and realities, especially in developing countries.

\section{ACKNOWLEDGEMENTS}

The cooperation of the Municipality of Canoas, the Department of Public Health, and the population of the Sao Luis District are gratefully acknowledged. 


\section{REFERENCES}

1. Sisinno CLS. Resíduos sólidos, ambiente e saúde: uma visão multidisciplinary Rio de Janeiro: Fiocruz; 2000.

2. Pratt LG. Household hazardous waste minimization program. In: Freeman HM, editor. Hazardous waste minimization. New York: McGraw-Hill; 1990. p. 253-259.

3. Tchobanoglous G, Kreith F. Handbook of solid waste management. New York: McGraw-Hill; 2002.

4. United States Environmental Protection Agency. Household hazardous waste [Internet]. [Cited 2015 jan 18]. Available from: http://www.epa.gov/ epawaste/conserve/materials/hhw.htm\#options

5. Slack RJ, Gronow JR, Voulvoulis N. The management of household hazardous waste in the United Kingdom. J Environ Manage. 2009;90(1):36-42. http:// dx.doi.org/10.1016/j.jenvman.2008.03.007. PMid:18423843.

6. Inglezakis VJ, Moustakas K. Household hazardous waste management: a review. J Environ Manage. 2015;150:310-21. http://dx.doi.org/10.1016/j. jenvman.2014.11.021. PMid:25528172.

7. Mexico. Cámara de Diputados del H. Congreso de la Unión [Internet] Ley General del Equilibrio Ecológico y la Protección al Ambiente. Diario Oficial de la Federación; Mexico; 09 Jan 2015 [Cited 2015 Jan 14]. Available from: http://www.diputados.gob.mx/LeyesBiblio/pdf/148_090115.pdf

8. Delgado OB, Ojeda-Benitez S, Márquez-Benavides L. Comparative analysis of hazardous household waste in two mexican regions. Waste Manag. 2007;27(6):792-801. PMID: 16820287.

9. Brasil. Ministério do Meio Ambiente [Internet]. Política Nacional de Resíduos Sólidos. [Cited 2015 Jan 17]. Available from: http://www.mma. gov.br/pol\%C3\%ADtica-de-res\%C3\%ADduos-sólidos

10. Gomes JA, Ogura SK. Componentes potencialmente perigosos presentes no lixo doméstico. São Paulo: IPT; 1993.

11. London Borough of Bexley. Hazardous Waste: Clinical Waste, Household Hazardous Waste Collection and Disposal Service (HWCDS) and Waste Electronic and Electrical Equipment (WEEE) [Internet]. [Cited 2015 Jan 17). Available from: http://www.bexley.gov.uk/?articleid $=15469$

12. Chartered Institute of Environmental Health. Good housing leads to good health: a toolkit for environmental health practitioners [Internet]. [Cited 2015 Jan 17]. Available from: http://www.cieh.org/policy/good_housing_ good_health.html

13. Larini L. Toxicologia. 3rd ed. São Paulo: Mamole; 1997.

14. Wollf E, Schwabe WK, Lange LC. Situação atual das pilhas e baterias no Brasil: aspectos ambientais e legislação. In: Anais do $9^{\circ}$ SILUBESA Simpósio Luso-Brasileiro de Engenharia Sanitária e Ambiental; 2000 Apr 9-14; Porto Seguro, BR. Porto Seguro: ABES/ABRH; 2000. (CD-ROM).

15. Ott WR, Roberts JW. Everyday exposure to toxic pollutants. Environmental regulations have improved the quality of outdoor air. But problems that persist indoors have received too little attention [Internet]. Sci Am. 1998:8691. [Cited 2012 Oct 15]. Available from: http://www2.gsu.edu/ mstnrhx/ toxic.pdf

16. Pichat P. A gestão dos resíduos. Lisboa: Instituto Piaget; 1998.

17. Peres F. É veneno ou é remédio?: agrotóxicos, saúde e ambiente. Rio de Janeiro: FIOCRUZ; 2003
18. World Health Organization. Heavy metal contamination: summary of monitoring emergencies [Internet]. [Cited 2015 Jan 17]. Available frome: http://www.paho.org/disasters\%20/index.php?option=com_content\&view $=$ section\&id $=144 \&$ layout $=$ blog\&Itemid $=1134 \&$ lang $=$ en\&limitstart $=216$

19. Järup L. Hazards of heavy metal contamination. Br Med Bull. 2003;68(1):16782. http://dx.doi.org/10.1093/bmb/ldg032. PMid:14757716.

20. Rosa WA, Labate RC. Programa saúde da família: a construção de um novo modelo de assistência. Rev Lat Am Enfermagem. 2005;13(6):1027-34. http://dx.doi.org/10.1590/S0104-11692005000600016. PMid:16444409.

21. The Lancet. Health in Brazil. 2011. [Cited 2015 Jan 16]. Available from: http://www.thelancet.com/series/health-in-brazil

22. Paim J, Travassos C, Almeida C, Bahia L, Macinko J. The Brazilian health system: history, advances, and challenges. Lancet. 2011;377(9779):1778-97. http://dx.doi.org/10.1016/S0140-6736(11)60054-8. PMid:21561655.

23. World Health Organization. Country cooperation strategy at a glance [Internet]. [Cited 2015 Jan 16]. Available from: http://www.who.int/ countryfocus/cooperation_strategy/ccsbrief_bra_en.pdf

24. Pinto RM, Wall M, Yu G, Penido C, Schmidt C. Primary care and public health services integration in Brazil's unified health system. Am J Public Health. 2012;102(11):e69-76. http://dx.doi.org/10.2105/AJPH.2012.300972. PMid:22994254.

25. Brasil. Ministério da Saúde. Departamento de Atenção Básica [Internet]. Atenção básica e a Saúde da Família. [Cited 2011 Oct 3]. Available from: http://dab.saude.gov.br/atencaobasica.php

26. Instituto Brasileiro de Geografia e Estatística. Cidades@: Canoas. [Internet]. [Cited 2012 May 30]. Available from: http://www.ibge.gov.br

27. Instituto de Pesquisa Econômica Aplicada. Diagnóstico dos resíduos sólidos urbanos: relatório de pesquisa. Brasilia: IPEA; 2012.

28. Canoas. Prefeitura Municipal. Informativos - manuais e cartilhas: guia sobre a coleta seletiva de Canoas [Internet]. [Cited 2012 May 18]. Available from: http://www.canoas.rs.gov.br/site/midia/imprensa/id/10

29. Ezpeleta J, Rockwell E. Pesquisa participante. Sao Paulo: Cortez Editora; 1989.

30. Baldin N, Munhoz EMB. Snowball (Bola de Neve): uma técnica metodológica para pesquisa em educação ambiental comunitária. In: Anais $10^{\circ}$ Congresso Nacional de Educação - EDUCRE; Anais do $1^{\circ}$ Seminário Internacional de Representações Sociais, Subjetividade e Educação - SIRSSE; 2011 Nov 7-10; Curitiba, BR. Curitiba: PUCPR. p. 329-41.

31. Chavis DM, Wandersman A. Sense of community in the urban environment: a catalyst for participation and community development. Am J Community Psychol. 1990;18(1):55-64. http://dx.doi.org/10.1007/BF00922689.

32. Vaske JJ, Kobrin KC. Place attachment and environmentally responsible behavior. J Environ Educ. 2001; 32(4):16-21. http://dx.doi. org/10.1080/00958960109598658.

33. World Health Organization. Types of healthy settings: healthy cities [Internet]. [Cited 2015 Jan 20]. Available from: http://www.who.int/healthy_settings/ types/cities/en/

34. Modebe IA, Onyeonoro UU, Ezeama NN, Ogbuagu CN, Agam NE. Public health implication of household solid waste management in Awka South 
East Nigeria. [Internet]. Int J Public Health. 2009;1:1-5. [cited 2015 Jan 14]. Available from: https://ispub.com/IJPH/1/1/12847

35. Kalinowski CM, Lynne GD, Johnson B. Recycling as a reflection of balanced self-interest: A test of the metaeconomics approach. Environ Behav. 2006;38(3):333-55. http://dx.doi.org/10.1177/0013916505279043.

36. Rushton L. Health hazards and waste management. Br Med Bull. 2003;68(1):183-97. http://dx.doi.org/10.1093/bmb/ldg034. PMid:14757717.

37. Silva PR, Ribeiro GTF. Acs: elo de ligação entre comunidade carente e a ESF. [Internet]. Vita et Sanitas. 2009;3:66-85. [Cited 2011 Nov 15]. Available from: www.fug.edu.br/revista_3/pdf/asc_elodeligacao.pdf
38. Rydin Y, Bleahu A, Davies M, Dávila JD, Friel S, De Grandis G, et al. Shaping cities for health: complexity and the planning of urban environments in the 21st century. Lancet. 2012;379(9831):2079-108. http://dx.doi.org/10.1016/ S0140-6736(12)60435-8. PMid:22651973.

39. Swan M. Emerging patient-driven health care models: an examination of health social networks, consumer personalized medicine and quantified self-tracking. Int J Environ Res Public Health. 2009;6(2):492-525. http:// dx.doi.org/10.3390/ijerph6020492. PMid:19440396.

Received on: Mar. 20, 2015

Accepted on: June 24, 2015 